\title{
Mapping recession risk for cultural heritage stone in Mexico City due to dry and wet deposition of urban air pollutants
}

\author{
Javier Omar CASTILLO-MIRANDA, ${ }^{1}$ Ricardo TORRES-JARDÓN, ${ }^{1}$ José Agustín GARCÍA-REYNOSO, ${ }^{1}$ \\ Bertha E. MAR-MORALES, ${ }^{1}$ Francisco Javier RODRÍGUEZ- GÓMEZ ${ }^{2}$ and Luis Gerardo RUIZ-SUÁREZ ${ }^{1 *}$
}

${ }^{1}$ Centro de Ciencias de la Atmósfera, Universidad Nacional Autónoma de México, Circuito de la Investigación Cientifica s/n, Ciudad Universitaria, 04510 Ciudad de México, México

${ }^{2}$ Departamento de Ingeniería Metalúrgica, Facultad de Química, Circuito Exterior s/n, Ciudad Universitaria, 04510 Ciudad de México, México

*Corresponding author; email: ruizs@unam.mx

Received: July 22, 2015; accepted: January 27, 2017

\begin{abstract}
RESUMEN
La contaminación del aire representa una amenaza para el patrimonio cultural, ya que acelera el deterioro natural de monumentos, edificaciones, iglesias y vestigios arqueológicos cuyo valor es irremplazable. En la Zona Metropolitana del Valle de México (ZMVM) hay 19968 edificaciones registradas como monumentos arqueológicos, artísticos o históricos. Algunas de ellas están construidas con roca calcárea (piedra caliza o mármol); en muchas otras los materiales utilizados son andesita, tezontle y piedra volcánica. En este trabajo se analiza por primera vez la distribución espacial del riesgo potencial de deterioro de piedra calcárea en términos de erosión superficial, con relación al patrimonio cultural mexicano ubicado en la ZMVM para el año base 2007. Para estimar el riesgo se utilizó la función de daño de Lipfert, que sólo es aplicable a las piedras carbonatadas de baja y mediana porosidad, las cuales incluyen piedra caliza y marfil de densidad media a alta. El mármol blanco de Carrara tiene una densidad de $2.69 \mathrm{~g} \mathrm{~cm}^{-3}$ y una porosidad de $0.37 \%$, en tanto que la piedra caliza tiene una densidad de 2.2-2.6 $\mathrm{g} \mathrm{cm}^{-3}$ y una porosidad de 5-20\%. En la piedra caliza de alta porosidad (baja densidad), la función sería aplicable con una subestimación potencial. En esta función, la tasa anual de erosión es a su vez una función de los promedios anuales de precipitación, $\mathrm{pH}$, y deposición seca de $\mathrm{SO}_{2} \mathrm{y} \mathrm{HNO}_{3}$. Se interpolaron en un sistema de información geográfica datos de varias redes de monitoreo meteorológico, la red de monitoreo de calidad del aire y deposición ácida de la ZMVM, y un modelo en 3D de la misma ZMVM, con el fin de obtener capas de mapa para estas variables. Estos mapas superpuestos se usaron para aplicar las funciones de Lipfert a coordenadas específicas de una pequeña muestra de monumentos artísticos o históricos relevantes. La complejidad de los gradientes de clima, patrones de vientos y distribución de emisiones dentro de la megalópolis mexicana inducen gradientes de hasta $50 \%$ en las tasas de erosión estimadas con la función de Lipfert en sitios cercanos en los cuales se utilizaron los mismos materiales de construcción. La Comisión Ambiental de la Megalópolis divide la ZMVM en cinco sectores. En 1990, las diferencias en las tasas de erosión entre dichas zonas eran tan amplias como las existentes entre los valores estimados para Oviedo, París y Praga en Europa durante el periodo 1980-2000. Las tasas de erosión disminuyeron alrededor de 50\% de 1997 a 2007 (el año base para este informe) gracias al éxito de las acciones de control de la contaminación del aire enfocadas a la protección de la salud pública. No obstante, aún se esperan altos gradientes de erosión para las piedras carbonatadas dentro de la ZMVM. Los valores de erosión reportados en este trabajo deben tomarse como estimaciones conservadores debido al desempeño aún imperfecto de los modelos 3D de calidad del aire en la meteorología urbana, así como al alto grado de incertidumbre en la modelación de inventarios de emisiones. En este sentido, el más notable es el inventario de emisiones de $\mathrm{SO}_{2}$. Estos mapas obligan a la creación de un programa para la determinación experimental de tasas de erosión que abarquen gran parte del singular patrimonio cultural mexicano; asimismo, deben añadirse a los mapas de niveles críticos obtenidos para la exposición de personal, cultivos y ecosistemas con el fin de estimar de forma adecuada el costo real de la contaminación del aire en la ZMVM y su área circundante.
\end{abstract}




\begin{abstract}
Air pollution is a threat to cultural heritage because it accelerates the natural deterioration of monuments, palaces, churches, and archaeological ruins, which have an irreplaceable value. In the Mexico City Metropolitan Area (MCMA), there are 19968 buildings registered as archaeological, historic, or artistic monuments. Some are built with calcareous rocks (limestone and marble) but many of them are made with andesite, tezontle and tuff stone. This paper reports for the first time the spatial distribution of the potential risk of deterioration on calcareous rocks in terms of surface recession with regard to Mexican cultural heritage in the MCMA for the base year 2007. The risk estimate was performed using Lipfert's damage function, only applicable to carbonate stones of medium and low porosity. These include mainly medium/high density limestone and marble. Carrara white marble has a density of $2.69 \mathrm{~g} \mathrm{~cm}^{-3}$ and a porosity of $0.37 \%$, and limestone has a density of 2.2-2.6 $\mathrm{g} \mathrm{cm}^{-3}$ and a porosity of 5-20\%. For high porosity (low density) limestone the function would be applicable with a potential under-estimation. In this function, annual recession rate is a function of annual averages of precipitation, $\mathrm{pH}$, and dry deposition of $\mathrm{SO}_{2}$ and $\mathrm{HNO}_{3}$. Data from several meteorological monitoring networks, the MCMA air quality and acid deposition monitoring networks, and a 3D air quality model (MCCM) were interpolated in a GIS in order to obtain map layers for these variables. These overlaid maps were used to apply the Lipfert functions at the specific coordinates of a small sample of relevant historic or artistic monuments. The complexity of climate gradients, wind patterns, and emissions distribution within the Mexico Megacity leads to gradients as large as 50\% in estimated recession rates using the Lipfert function at nearby sites made of the same type of building materials. The Comisión Ambiental de la Megalópolis (Environmental Commission of the Megacity) divides the MCMA into five sectors. Differences in recession rates between them were, in 1990, as large as those between estimated values for Oviedo, Paris, and Prague in Europe for the period 1980-2000. Recession rates decreased by about 50\% from 1990 to 2007, the base year for this report, due to the success of air pollution control actions focused on the protection of public health. Nevertheless, strong recession gradients are still expected for carbonate stone within the MCMA. The recession values reported in this work must be taken as conservative estimates due to the not yet optimal performance of 3D air quality models in urban meteorology and the high degree of uncertainty in modeling emissions inventories. Most notable is the $\mathrm{SO}_{2}$ emissions inventory. These maps call for a program of experimental determination of recession rates for building materials that comprise a very large part of Mexico's unique cultural heritage. These maps should also be added to the critical level maps obtained for human exposure, crops, and ecosystems in order to properly estimate the actual cost of air pollution in the MCMA and the area under its influence.
\end{abstract}

Keywords: Cultural heritage, air pollution, MCMA, Mexico Megacity, recession rates.

\section{Introduction}

Materials exposed to the environment are at risk of degradation through natural wearing processes. Since the mid-nineteenth century, air pollution has been identified as a factor that accelerates material degradation in natural and manmade materials (Cultrone et al., 2004). The irreplaceable value of the cultural heritage inherent to monuments, palaces, churches, and archaeological ruins is threatened by air pollution. Previous observations regarding many monuments and buildings with historical value have shown that accelerated deterioration is correlated with increases in urbanization, industrialization, and associated fossil fuel consumption.

The vast majority of rocks are composed of two or more different minerals. These minerals are joined in a strong structure that characterizes the stone and partly determines its color, durability, and physical and chemical properties (Winkler, 1997).

\subsection{Surface recession of carbonate stones}

In the natural dissolution of stone, there is a strong correlation between surface recession and open porosity. An open pore structure allows for more water intake by the stone, increasing the dissolution of carbonate minerals (Grossi et al., 1995). Acidic gases are absorbed into the stone according to its moisture content, which is determined largely by the properties that affect moisture transfer. These properties include absorption, liquid water permeability, hygroscopic moisture content, evaporation, and permeability in the vapor phase. These properties may be related to pore size distribution (Grossi and Murray, 1999). 
Franzoni and Sassoni (2011) exposed various types of stones, mostly containing calcite and dolomite, to a wear process in acidic solutions. With regard to the soluble fraction, the average weight loss increased by a factor of 2.3 when the solution's $\mathrm{pH}$ decreased from 5.6 to 4.0. When the $\mathrm{pH}$ was changed from 5 to 4 , the weight loss factor was increased by a factor of 1.34 . They concluded that there is a correlation between the microstructural features and the weathered rock material and established that the rate of recession depends on open porosity and the specific surface.

The deterioration of certain materials has primarily been documented in European cities and is characterized by calcium sulfate or gypsum shell $\left(\mathrm{CaSO}_{4} \cdot 2 \mathrm{H}_{2} \mathrm{O}\right)$ formation, resulting from high air concentrations of sulfur dioxide $\left(\mathrm{SO}_{2}\right)$. Fassina (1978) identified gypsum formation as the process underlying masonry deterioration in an artistic heritage site in Venice. Skoulikidis and Papakonstatinou-Ziotis (1981) noted that accelerated statue and monument deterioration in the Acropolis of Athens is related to dry deposits of atmospheric $\mathrm{SO}_{2}$ on the limestone and marble surfaces and their subsequent conversion to gypsum, caused by intense industrialization in this area. According to these authors, this polluting gas may have generated 85 to $97 \%$ of the gypsum detected, causing deterioration in these materials.

The walls of St. Rumbold's Cathedral (Mechelen, Belgium) were constructed from limestone in the thirteenth and fifteenth centuries, and erosion in these walls has been attributed to gypsum formation. The abundance of sulfate anion in runoff waters confirmed gypsum formation; the runoff water samples were used to calculate an approximate average surface recession of $20 \mu \mathrm{m}$ (Roekens and Van Grieken, 1989). Cobourn (1993) experimented with gypsum $\left(\mathrm{CaSO}_{4} \cdot 2 \mathrm{H}_{2} \mathrm{O}\right)$ and epsomite $\left(\mathrm{MgSO}_{4} \cdot 7 \mathrm{H}_{2} \mathrm{O}\right)$ formation in a humid atmosphere over marble and dolomite surfaces through $\mathrm{SO}_{2}$ absorption. For both dolomite and marble, the $\mathrm{SO}_{2}$ deposition rate increased as liquid water increased on the surface.

Studies of the effects of acid deposition on carbonate rocks in the US National Assessment Program on Acid Precipitation quantify erosion of stone. Chemical analyses of rain runoff solutions show that approximately $30 \%$ of erosion by dissolution may be attributed to wet deposition of hydrogen ion and dry deposition of sulfur dioxide and nitric acid between rain events. The remaining approximately $70 \%$ of dissolution erosion is explained by the leaching of carbonate rocks exposed to rain water in equilibrium with atmospheric carbon dioxide (Baedecker et al., 1992). Research on the effect of acid rain on carbonate rocks yielded a $17 \%$ contribution to chemical erosion on marble and $10 \%$ on limestone (Baedecker and Reddy, 1993). The observable damage on limestone with a relatively high iron concentration in eighteenth-century buildings in central Stockholm has been largely attributed to acid rain (Nord and Tronner, 1995).

Portland stone samples were exposed to the environment at various sites in southeastern England. A loss of material, equivalent to $16 \mu \mathrm{m} \mathrm{yr}^{-1}$ was observed for sites located in Central London, while a loss of $10.316 \mu \mathrm{m} \mathrm{yr}^{-1}$ was observed for rural sites. This stone wear was caused by the formation of gypsum due to direct reaction with both $\mathrm{SO}_{2}$ and sulfuric acid (Jaynes and Cooke, 1987).

Delopoulou and Sikiotis (1992) used a reactor (FP-R) in a sample train containing Pentelic marble grains, with the additional use of a filter package, to determine the effect of pollutant gases. They explained that the formation of $\mathrm{Ca}\left(\mathrm{NO}_{3}\right)_{2}$ was probably due to the reaction of $\mathrm{HNO}_{2}$ with marble followed by the oxidation of the obtained nitrite to nitrate, or by oxidation of $\mathrm{HNO}_{2}$ to $\mathrm{HNO}_{3}$ and the subsequent reaction with marble. Laboratory studies of $\mathrm{HNO}_{3}$ retention on marble were done, varying the following parameters: relative humidity, the flow velocity of the $\mathrm{HNO}_{3}$ mixture, the mass of the stone, grain size, and $\mathrm{HNO}_{3}$ concentration. It was shown that nitric acid is a good corrosive agent for marble. Sikiotis and Kirkitsos (1995) showed that calcareous stones (Pentelic marble, Portland limestone, and Baumberger sandstone) are appropriate sinks for gaseous $\mathrm{HNO}_{3}$. Regardless of its low porosity, at high relative humidity, marble was more vulnerable to attack by $\mathrm{HNO}_{3}$ than limestone and sandstone. Kirkitsos and Sikiotis (1996) also concluded that gaseous $\mathrm{HNO}_{3}$ is more corrosive than $\mathrm{NO}_{2}$ for marble monuments, despite the considerable low concentrations of $\mathrm{HNO}_{3}$.

Fenter et al. (1995) studied the reaction of gaseous $\mathrm{HNO}_{3}$ on calcite in a flow reactor at low pressure and found that $\mathrm{HNO}_{3}$ is absorbed on the solid with a 
very high efficiency. Identification of $\mathrm{H}_{2} \mathrm{O}$ and $\mathrm{CO}_{2}$ as products suggests that the reaction of nitric acid with limestone is governed by the following equation:

$$
\begin{aligned}
& \mathrm{CaCO}_{3(\mathrm{~s})}+2 \mathrm{HNO}_{3(\mathrm{~g})} \rightarrow \mathrm{Ca}\left(\mathrm{NO}_{3}\right)_{2(\text { ads })}+ \\
& \mathrm{CO}_{(\mathrm{g})}+\mathrm{H}_{2} \mathrm{O}_{(\mathrm{g})}
\end{aligned}
$$

The reduction in the use of coal as an energy source is causing a decrease in $\mathrm{SO}_{2}$ concentration levels in European cities. In Mexico, the substitution of fuel oil rich in sulfur, by natural gas in power plants has had a similar effect. In turn, the increased use of the automobile makes necessary to consider the role of nitrogen oxides, chlorides and ozone as accelerators of the sulfation reaction or as direct agents on the deterioration of materials. In fact, a marked increase in the amount of deterioration is seen when the stone is exposed to a combination of $\mathrm{SO}_{2}, \mathrm{NO}_{\mathrm{x}}$ and $\mathrm{O}_{3}$ (Massey, 1999). Allen et al. (2000) found that the presence of $\mathrm{NO}_{2}$ accelerates the rate of sulfation of limestone helping the oxidation of $\mathrm{SO}_{2}$ to $\mathrm{SO}_{3}$ that commonly is a slow process. In another route, $\mathrm{SO}_{3}$ in water reacts with limestone to form $\mathrm{CaSO}_{4}$. Also, iron rich suspended particles, often from diesel vehicles, can increase the oxidation of $\mathrm{SO}_{2}$ on the stone surface (Grossi and Brimblecombe, 2002).

Black scabs found in European monuments and buildings located in urban environments contain molecular markers characteristic of petroleum products (Saiz-Jiménez and Hermosín, 2004). There has been a shift from high levels of sulfate deposition; nitrogen compounds and diesel soot now predominate in stones (Grossi and Brimblecombe, 2007). The presence of $\mathrm{NO}_{2}$ in photochemical smog ensures nitric acid formation; therefore, its relative importance to corrosion of old buildings and artifacts has increased (Tzanis et al., 2009).

Output from air quality numerical models was used to apply the Lipfert damage function (Lipfert, 1989 ) in order to produce maps of recession rates of materials. Cultural heritage sites in London and Barcelona were used to validate this method (Watt et al., 2007). Spatial mapping of combined observations and modeled data has been used to establish public policies and to understand the spatial character of air quality trends in Europe (Denby et al., 2010).

Using the micro-erosion meter method (MEM), erosion rates were determined for limestone at
St. Paul's Cathedral for decadal periods (1980-1990, 1990-2000, and 2000-2010). These rates were compared with recession rates derived from applying the Lipfert damage function (Lipfert, 1989) to available data on rain and $\mathrm{SO}_{2}$ in central London for the same periods. Erosion rates were 3.33 and 2.77 times higher than the recession rates in the 1980 s and 2000 s, respectively. The observed decrease in ratios was attributed to the decrease in $\mathrm{SO}_{2}$ levels (Inkpen et al., 2012).

\subsection{Monument deterioration in Mexico}

Some studies on monument deterioration in Mexico were found in the literature, mostly focused on evaluating and restoring this damage (Bravo et al., 1994, 1995). An analysis of ignimbrite (a type of rhyolite rich in $\mathrm{SiO}_{2}$ ) blocks in the Morelia cathedral (state of Michoacán) indicated that they had deteriorated by exposure to $\mathrm{SO}_{2}$. This was suggested by a correlation between their mechanical strength and the $\mathrm{SO}_{2}$ levels in the air, most likely from motor vehicles and a paper factory (Alonso and Martínez, 2003). A field study correlated limestone deterioration at archaeological sites in coastal areas in southeastern Mexico with rainwater acidity (Bravo et al., 2006). In Puerto Morelos, Quintana Roo, Mexico, precipitation was characterized by $\mathrm{pH}$ values of 5.35 for an average weighed volume; in certain instances, the pH was as low as 4.6 (Bravo et al., 2000). In the city of San Francisco de Campeche, Mexico, included on the UNESCO Cultural Heritage List, the Forts of San Carlos and San Pedro were built with limestone rocks. The degradation observed in these buildings was generally attributed to the volume and intensity of precipitation. However, the existence of gypsum samples from the Fort of San Pedro revealed the influence of $\mathrm{SO}_{2}$ emissions from vehicular and industrial sources in the region, including offshore oil platforms (Reyes et al., 2011).

Several studies have also been published on the primary polluting agents that contribute to such deterioration on a regional level (Martínez-González, 1992; Alonso and Martínez, 2003; Bravo et al., 2000, 2006). The aforementioned experimental studies include the identification of the mechanisms for dissolution of calcium ions in stone. Artificial acid solutions composed of sulfuric acid were used in the dissolution. These studies showed that the calcium 
dissolution rate is slower in stone with a high percentage of $\mathrm{SiO}_{2}$ (Martínez-González, 1992). Atmospheric corrosion maps for metals in Mexico were created using the ISO 9223 standard classification system. This work required average annual corrosion values for test stations as well as meteorological and air pollution data, such as $\mathrm{SO}_{2}$ and chloride ions $\left(\mathrm{Cl}^{-}\right)$ (Mariaca et al., 1999).

\subsection{Air pollution in the Mexico City Metropolitan Area}

Studies evaluating the damage to cultural heritage sites in the MCMA have focused on rainwater acidity as the key factor (Martínez-González, 1992). In addition, the MCMA has serious air pollution problems that impact public health (SMA, 2008) as well as crops and ecosystems (Fenn et al., 2002; Ortiz-Garda et al., 2002); thus, it is likely that such pollutants also damage the cultural heritage sites. $\mathrm{SO}_{2}$ is considered one of the main pollutants in the MCMA. However, erosion and deterioration of stone in the Valley of Mexico is affected by four main factors: the extreme pollution in the metropolitan area, the semi-arid subtropical climate, the specific hydrological situation, and frequent seismic activity (Wedekind et al., 2011).

$\mathrm{SO}_{2}$ is generated by burning fuels with sulfur, emitted by volcanoes and, to a lesser extent, produced by certain industrial processes such as smelting and petroleum refining. Due to the growth of the city, including its industrial sector, $\mathrm{SO}_{2}$ became a serious pollution problem in the early 1970s. Jáuregui et al. (1981) found that this problem was due to the use of sulfur-rich fuels. Also, an oil refinery was located within the city limits. $\mathrm{SO}_{2}$ concentration levels were higher in the north of the MCMA, where most industries were located. $\mathrm{SO}_{2}$ was also spatially distributed in a north-south direction due to the city's westerly winds. In a six-month sampling study from January to July 1959, Bravo (1960) reported that the $\mathrm{SO}_{2}$ levels in the northwestern part of the city reached an average 24-h concentration of $1.28 \mathrm{ppm}$ and an average monthly maximum of $0.33 \mathrm{ppm}$. Furthermore, the $\mathrm{SO}_{2}$ concentration in the southwestern part of the MCMA reached an average 24-h maximum of 0.42 ppm; however, over the six-month study, it averaged a monthly maximum of $0.08 \mathrm{ppm}$. As a reference, the World Health Organization suggests 0.047 ppm for the average concentration over $24 \mathrm{~h}$ (WHO, 2006).
In 1990, the average hourly concentrations for $\mathrm{SO}_{2}$ in the MCMA (90th percentile) reached $0.115 \mathrm{ppm}$. In 2007, this percentile was reduced to $0.027 \mathrm{ppm}$ (SMA, 2008); nevertheless, between 2000 and 2005, the MCMA was still recognized as the primary urban area in Latin America with high $\mathrm{SO}_{2}$ levels (WHO, 2006). It is worth mentioning that this region is still influenced by major anthropogenic sources such as the Tula industrial complex, located north of the MCMA. The MCMA is also affected by natural sources, such as the Popocatépetl volcano east of the urban area, which produces emissions that occasionally affect the urban area (Garda-Escalante, 2008; De Foy et al., 2009a, b). Acid rain records for the MCMA indicate relatively high acidity in the 1990s for the western portion of the region, with a gradient toward neutral values in the east. Such conditions have changed over time, and in 2007 only a small area southwest of the city maintained such acidity. The reduced acidity tended toward neutrality for the areas north and northeast of the MCMA (SMA, 2008). Due to its geographic position, the Valley of Mexico has a rainy season between June and September; thus, the lowest yearly pollution levels were recorded during these months. The dry season yields the highest concentrations of $\mathrm{SO}_{2}$ and other pollutants (SMA, 2009). Therefore, archaeological, historic, and artistic monuments in the MCMA are likely to be at risk during the entire year due to pollutants such as $\mathrm{SO}_{2}$ and acid precipitation.

There are few studies of $\mathrm{HNO}_{3}$ levels in the MCMA and virtually none that address the spatial distribution of these levels. Available data indicate that this gaseous species exhibits a behavior that is somewhat similar to that of $\mathrm{O}_{3}$, with a maximum during the day and lower values at night. There is an apparent gradient increase from north to south-southwest (Moya et al., 2004; Rosas-Pérez et al., 2006; Zheng et al., 2008; Wood et al., 2009; Cuevas, 2014). The major source of $\mathrm{HNO}_{3}$ is the reaction of $\mathrm{NO}_{2}$ with the $\mathrm{OH}$ radical.

Measurements of $\mathrm{HNO}_{3}$ in 2010 in the southwestern part of the MCMA (Cuevas, 2014) indicate that from midnight until 05:00 LT, $\mathrm{HNO}_{3}$ levels remain around $2 \mathrm{ppb}$. The rapid accumulation of this species begins shortly before dawn. The maximum value of the medians (3.9 ppb) is reached between 09:00 and 10:00 LT within a narrow range ( 3 and $5 \mathrm{ppb}$ in the 
25th and 75th percentiles), in apparent coincidence with values for $\mathrm{NO}_{2}$. The maximum value of $\mathrm{HNO}_{3}$ in this period was about $6.5 \mathrm{ppb}$. However, from this period until 13:00 LT, the medians decrease to about $2.5 \mathrm{ppb}$ with an increased uncertainty, as the 25 th and 75 th percentiles range from 2 to $8 \mathrm{ppb}$, respectively, with major peaks at $10 \mathrm{ppb}$. This suggests that in the morning there is a net production of $\mathrm{HNO}_{3}$ due to the reaction of $\mathrm{NO}_{2}$ with $\mathrm{OH}$. Once the $\mathrm{OH}$ radical maximum is reached, a competition for $\mathrm{NO}_{2}$ is established with other organic radicals. $\mathrm{HNO}_{3}$ also forms aerosols with $\mathrm{NH}_{3}$. Moreover, there is a strong $\mathrm{HNO}_{3}$ removal caused by contact with surfaces due to intensified atmospheric turbulence. By the afternoon, $\mathrm{HNO}_{3}$ levels are low mainly due to a lower formation rate. At night, the remaining $\mathrm{HNO}_{3}$ can be converted to $\mathrm{NH}_{4} \mathrm{NO}_{3}$ and dry deposition mechanisms rapidly remove the low remaining $\mathrm{HNO}_{3}$ concentrations. Since $\mathrm{HNO}_{3}$ is soluble in water, it is expected that in the rainy season its concentrations are in parts per trillion.

Given this background, the purpose of this study was to build surface recession maps for carbonate materials in the MCMA. These recession maps were created using the Lipfert damage function (Lipfert, 1989). A small sample of historic and artistic monuments in the MCMA built with carbonate stones was selected. Maps of the parameters necessary for the application of the Lipfert function were constructed by combining data from monitoring networks with the results of air quality models. This is the first work done in Mexico that shows a spatial estimation of the deterioration risk of cultural heritage in the MCMA due to exposure to high levels of air pollution.

\section{Methods}

\subsection{Types and properties of stones}

The stones found in Mexico's historic buildings are andesite, tezontle, and tuff (Pirella and Ramírez, 2001) and calcareous stones. The latter can be classified as sedimentary (limestone and dolostone) and metamorphic (marble). Limestone is mainly composed of calcite $\left(\mathrm{CaCO}_{3}\right)$ and dolostone mainly of dolomite $\left(\mathrm{CaMg}\left(\mathrm{CO}_{3}\right)_{2}\right)$ minerals.

One kind of carbonate stone found in Mexico's historic monuments is the Tepotzotlán gargoyle stone. This is an unconsolidated hybrid tuff with a very porous matrix made of carbonate and dolomite in the interior edges, and it also contains clay and glass. Its porosity ranges from 34 to $40 \%$ with a density of 1.3 to $1.6 \mathrm{~g} \mathrm{~cm}^{-3}$ (Martínez-González, 1992). It is also possible to find a type of red limestone on the pedestal of the monument to Christopher Columbus with a density of $2.2-2.6 \mathrm{~g} \mathrm{~cm}^{-3}$ and a porosity of 5-20\% (Winkler, 1997).

Metamorphic rocks are igneous or sedimentary rocks recrystallized by the effects of temperature and pressure. Recrystallization of limestone results in marble. Marble is composed of large, interlocking calcite crystals, which form the recrystallization of smaller grains in the parent rock (Tarbuck et al., 2005). Carrara white marble is found in the Palacio de Bellas Artes, Hemiciclo a Juárez, the statues at the Columna de la Independencia, and the Monumento a los Niños Héroes. Carrara white marble has a density of $2.69 \mathrm{~g} \mathrm{~cm}^{-3}$ and porosity of $0.37 \%$ (ASTM, 1979), and in accordance with its density value is classified as class III (high density) (ASTM, 1996).

\subsection{Selection of the damage functions}

Several surface recession functions for stones have been developed, mainly in Europe. Haynie et al. (1976) focused on white Cherokee marble; Livingston (1992) on carbonate stone; Webb et al. (1992) worked on samples of Portland limestone; Baedecker et al. (1992) on marble and limestone; while Tidblad et al. (1998, 2001) studied Portland limestone and dolomite as well as white Mansfield sandstone. Empirical recession functions were developed as part of large European projects (Kucera, 2005; Kucera et al., 2007).

Damage functions available in the literature often use nonlinear regression equations. Only a few have a theoretical and mechanistic approach. It is desirable that the damage functions represent a large number of buildings and various types of stone (Brimblecombe and Grossi, 2008). To this end, it is advisable not to ignore the petrophysical properties of rocks. These properties account for the degree and type of wear due to the strong correlation of recession with open surface porosity (Grossi et al., 1995). Damage functions express the quantitative relationship between pollutant concentrations, meteorological variables, and deterioration of the material (Grossi et al., 2008). The damage function postulated by Lipfert (1989) for generic calcite 
considers a model of limestone and marble of medium and high density (ASTM, 1996). The function assumes a constant stone density of $2.7 \mathrm{~g} \mathrm{~cm}^{-3}$. However, there are stones such as Portland and Hontoria with porosity of $20 \%$ and a density close to $2.0 \mathrm{~g} \mathrm{~cm}^{-3}$ (Bonazza et al., 2009).

Acid rain dissolution models were used to estimate the chemical degradation of calcium carbonate rocks in buildings (Reddy et al., 1985). These models associated laboratory data on physical properties, providing the basis for the theoretical damage function. This function considers three mechanisms for the loss of stone material (Lipfert, 1989). The first is the dissolution of stone by 'clean' rain water at a $\mathrm{pH}>5.5$. This is due to the solubility of calcite as a function of atmospheric $\mathrm{CO}_{2}$, temperature, and porosity, as well as the physical characteristics of the stone. The second mechanism is the reaction with gas-phase $\mathrm{SO}_{2}$ and $\mathrm{HNO}_{3}$, which requires knowledge of their deposition rate. This allows for the estimation of the flow to the surface of the stone depending on weather conditions and the configuration of the stone. The third mechanism is the increased dissolution of stone by acid rain. This is affected by solubility equilibrium (Reddy et al., 1985) and by the kinetics of the dissolution rate (Lipfert, 1989).

Lipfert (1989) quantifies the annual recession of $\mathrm{CaCO}_{3}$ stone, considering the mechanisms of natural dissolution or karst effect, acid rain, and the deposition of pollutants:

$\mathrm{L}=18.8 \cdot \mathrm{R}+0.016 \cdot\left[\mathrm{H}^{+}\right] \cdot \mathrm{R}+$

$0.18\left(\mathrm{~V}_{\mathrm{dS}}\left[\mathrm{SO}_{2}\right]+\mathrm{V}_{\mathrm{dN}}\left[\mathrm{HNO}_{3}\right]\right)$

where $\mathrm{L}=$ yearly recession $\left(\mu \mathrm{m}\right.$ year $\left.^{-1}\right) ; 18.8$ is a constant based on the solubility of $\mathrm{CaCO}_{3}$ in equilibrium with $330 \mathrm{ppm}$ ( $\mu \mathrm{m} \mathrm{m}^{-1}$ of precipitation); $\mathrm{R}$ is the precipitation rate $\left(\mathrm{m} \mathrm{year}^{-1}\right) ; 0.016$ is a constant valid for rain $\mathrm{pH}$ between 3 to $\left.5 ; \mathrm{H}^{+}\right]$is the hydronium ion concentration $\left(\mu \mathrm{mol} \mathrm{L}{ }^{-1}\right)$ estimated from the annual $\mathrm{pH}$ of rainfall; and $\mathrm{V}_{\mathrm{dS}}$ and $\mathrm{V}_{\mathrm{dN}}$ are deposition rates $\left(\mathrm{cm} \mathrm{s}^{-1}\right.$ ) for $\mathrm{SO}_{2}$ and $\mathrm{HNO}_{3}$, respectively. Concentration units for these are given as $\mu \mathrm{g} \mathrm{m}^{-3}$. Table I shows the deposition rates used in the Lipfert function.

The carbonate rocks considered in this study are marble and limestone. Nitric acid is not commonly measured in air quality monitoring networks. The
Table I. Deposition rate of $\mathrm{SO}_{2}\left(\mathrm{~V}_{\mathrm{ds}}\right)$ and $\mathrm{HNO}_{3}\left(\mathrm{~V}_{\mathrm{dN}}\right)$ measured in field exposure tests.

\begin{tabular}{lcc}
\hline $\begin{array}{l}\text { Deposition rate } \\
\left(\mathrm{m} \mathrm{s}^{-1}\right)\end{array}$ & $\begin{array}{c}\text { Carrara } \\
\text { marble }^{3}\end{array}$ & $\begin{array}{c}\text { Portland } \\
\text { limestone }^{\mathrm{a}}\end{array}$ \\
\hline $\mathrm{VdS}$ & 0.38 & 0.89 \\
$\mathrm{VdN}$ & 0.32 & 0.54 \\
\hline
\end{tabular}

${ }^{a}$ Sabbioni, 2003.

availability of data is therefore limited. The following empirical function, derived in the MULTI-ASSESS project, allows for the estimation of nitric acid from $\mathrm{NO}_{2}, \mathrm{O}_{3}, \mathrm{Rh}$ and temperature data (Kucera, 2005):

$\left.\left[\mathrm{HNO}_{3}\right]=516 \cdot \mathrm{e}^{-3400 /(\mathrm{T}+273)}\left(\mathrm{NO}_{2}\right] \cdot\left[\mathrm{O}_{3}\right] \cdot \mathrm{Rh}\right)^{0.5}$

where $\left[\mathrm{HNO}_{3}\right]=$ concentration of $\mathrm{HNO}_{3} ; \mathrm{T}$ is temperature in ${ }^{\circ} \mathrm{C} ;\left[\mathrm{NO}_{2}\right]=$ concentration of $\mathrm{NO}_{2} ;\left[\mathrm{O}_{3}\right]=$ concentration of $\mathrm{O}_{3} ; \mathrm{Rhr}=$ relative humidity $(\%)$. All concentration units are in $\mu \mathrm{m} \mathrm{m}^{-3}$.

The estimation of nitric acid required the annual average hourly values from (3). Parameters were used from the databases generated by the Red Automática de Monitoreo Atmosférico (Automatic Atmospheric Monitoring Network, RAMA) (SMA, 2011) and the Red de Meteorología y Radiación (Solar Meteorology and Solar Radiation Network, REDMET) (SMA, 2011). These parameters are simultaneously monitored in nine stations: Tlalneplantla, Tacuba, ENEP-Acatlán, Chapingo, Xalostoc, Merced, Pedregal, Plateros, and Cerro de la Estrella.

\subsection{Calculation sequence}

To generate the recession map, the following steps were performed. First, the monuments were located and identified based on the data and criteria in official catalogues for the type of construction material. One category was used: calcareous (carbonate) stone (limestone and marble). In the second step, the available data on measured concentrations of sulfur dioxide $\left(\mathrm{SO}_{2}\right)$, hydronium ion $\left(\mathrm{H}^{+}\right)$, and meteorological parameters were integrated with results from an air quality numerical simulation model. The data and results were applied using mathematical functions suitable for the construction of spatial distribution maps through interpolation. Subsequently, these values were used to apply damage functions corresponding to a certain type of stone in order to 
generate the recession layers. In the next stage, the recession values for the historic or artistic monument were extracted from the recession layer according to the monument's geographic location in the MCMA. These steps are summarized and described in the following paragraphs.

\subsubsection{Classification and selection of the cultural heritage sites}

The Ley Federal sobre Monumentos y Zonas Arqueológicos, Artísticos e Históricos (Federal Law on Archaeological, Artistic, and Historic Monuments and Zones) of Mexico includes the following text: "Archaeological monuments are all those remains of pre-Hispanic cultures dating back to before 1521, the year when Mexico was conquered by Hernán Cortés. Historic monuments are the heritage of the colonial period (1521 to 1810 ) and of the rest of the nineteenth century. Artistic monuments are the architectural and urban heritage built after 1900". In this study, cultural heritage sites included historic and artistic monuments located in or close to the MCMA. Classification was based on the Instituto Nacional de Antropología e Historia (National Anthropology and History Institute, INAH) catalogue, which refers to 2300 archaeological monuments, 10500 historic monuments, and 7168 artistic monuments in the Federal District and the State of Mexico (CONACULTA, 2003). From these sites, which are protected by the Federal Executive, under custody of the INAH, and open to the public, a sample was selected. Then, the sample was arranged by geographical area and material type. The buildings constructed from carbonate stone comprise two historic and four artistic buildings. Their names and locations are shown in Table II; the labels for the sites in the figures correspond to the site-identifiers in this table.

\subsubsection{Database for damage function parameters}

In this study, $\mathrm{SO}_{2}$ data generated by (RAMA) were used (SMA, 2011) along with values produced using the Multiscale Climate Chemistry Model (MCCM), which employs mathematical simulations in order to approximate concentrations in areas for which measurements are not available. The MCCM was developed by the Institute of Meteorology and Climate Research-Atmospheric Environmental Research (IMK-IFU, German initials), affiliated with the Karlsruhe Institute of Technology, Germany; it combines meteorological and chemical processes. This model includes the gaseous phase, dry deposition, and anthropogenic and biogenic emission chemistry, and it also incorporates explicit descriptions of precipitation and cloud processes (Grell et al., 2000).

In order to establish the net base values for $\mathrm{SO}_{2}$ from interpolation, the average values measured at the stations were combined with the values generated using the MCCM model. The $\mathrm{SO}_{2}$ values from the model are representative and include a downward bias in the troposphere proximal to the surface (0$18 \mathrm{~m}$ ) for 2007. These results were generated for a domain with $31 \times 31$ cells with $3 \mathrm{~km}$ on each side. It is important to note that the MCCM model underestimates the $\mathrm{SO}_{2}$ concentrations because the entry data are $\mathrm{SO}_{2}$ concentration values from the 1999 data recorded by the national emissions inventory of the Instituto Nacional de Ecología (National Ecology Institute) of Mexico, which may not represent the MCMA conditions for 2007 (García-Reynoso, 2010). To compensate for this discrepancy, a provisional adjustment factor was generated based on a spatial and temporal comparison with the RAMA stations. Using this factor, the MCCM model concentrations were approximated with the RAMA station measurements. Using this adjustment, a 0.52 concordance index was calculated for $\mathrm{SO}_{2}$. The annual concentration values for $\mathrm{SO}_{2}$ include values from 26 monitoring stations (SMA, 2011) and the values estimated using the MCCM model.

For the hydronium ion $([\mathrm{H}+])$ concentrations, the data from the Red de Depósito Atmosférico (Atmospheric Deposit Network, REDDA) were collected for 2007 (SMN, 2011). The average annual concentrations for hydronium ions $([\mathrm{H}+])$ include values from 16 stations in this network.

Precipitation (rain) levels were collected from the following network databases: REDDA (SMA, 2011), PEMBU (PEMBU, 2011), and SMN (SMN, 2011); interpolation functions were then applied. The accumulated annual precipitation for 2007 includes values from 53 meteorological stations distributed throughout the Valley of Mexico air basin.

In addition, in order to estimate a possible trend with regard to recession rates resulting from the set of public-health-focused air pollution mitigation actions 
implemented in Mexico City, we used the same data sources, except for PEMBU, to estimate quadrant-averaged recession rates for Mexico City in 1990.

\subsection{Creating layers using a Geographical Informa- tion System}

\subsubsection{Selection of the interpolation method}

Under the Geographic Information Systems (GIS) paradigm, the layers represent a surface model that integrates statistical properties for the sample data (Canada, 2006). The layers can be created using deterministic interpolation methods such as the weighted mean through inverse-distance weighting (IDW) and the kriging geostatistical estimator described in Denby et al. (2005). The IDW method is based on the notion that proximal phenomena must have a greater influence on the estimated value than distal phenomena. Each measured point has a local influence, which is reduced linearly by the distance between the sampled and unsampled points. The intensity by which the local influence is reduced by distance is controlled by the weighting parameter "power". If this parameter is zero, the influence is not reduced by distance, the weight will be the same, and the projected value will be an average of the values measured. If "power" is very high, only the points in close proximity to the measured values will influence the estimated value. When the power value is 2 , the data are interpolated through the inverse distance squared. The kriging method is a geostatistics technique similar to IDW. It uses a linear combination of weighted values in known positions to estimate values in unknown positions. The kriging method considers the distance between the sampled points and their autocorrelation. Applying the kriging method implies that modeling the semivariogram describes spatial continuity for the data and how this continuity is modified by distance and direction. Similarly, the kriging method should consider the number of neighbors at the time of interpolation; it should consider the semivariogram mathematical function adjustment that best condenses the observed data. As a result, this mathematical function constructs the best interpolated layer. The selection of the layer depends on the optimum prediction values from the error statistics and the coefficient of determination $\mathrm{R}^{2}$.

An important property of the modeling performed using kriging is that it tends to eliminate extreme values; it produces lower estimation error and creates generalized smoothing, while IDW modeling tends to form islands around the sample points (Canada et al., 2010). Nevertheless, the two methods are considered acceptable for atmospheric science applications. The choice of method depends on the number of observations and their spatial arrangement (Rojas-Avellaneda, 2007; Kumar et al., 2011).The kriging method is a standard procedure commonly used in the European Monitoring and Evaluation Programme to create historic concentration maps (Denby et al., 2005). For example, the kriging method known as "simple kriging" is the method most commonly used to spatially analyze data on acid deposition. It uses an exponential function to model the semivariogram (Venkatram, 1988). The kriging method has also been applied to interpolate temperature data in 10-km cells using an exponential function (Philips and Marks, 1996). Ordinary kriging has been used to map the temporal trends in European air quality by considering $\mathrm{SO}_{2}$ (Denby et al., 2010).

The spatial representation in this study was developed using the ArcGIS software (ArcGIS 9, 2008); ArcGIS uses the "geostatistical analysis" extension, which includes advanced tools for exploratory analyses on spatial data and assists in the construction of statistical surfaces. Optimum layer construction depends on the use of the proper interpolation method, which is determined for constructing vector layers by using IDW and ordinary kriging for each parameter. These layers were transformed into raster layers for subsequent application in the damage functions. Then, the interpolation method was selected based on the best coefficient of determination $\mathrm{R}^{2}$ for the relationship between the observed and projected values at a single position, both in the vector and raster layers.

Kriging and a circular variogram model with five neighbors, or at least three, was used to interpolate the $\mathrm{SO}_{2}$ concentration layer yielding a coefficient of determination $\mathrm{R}^{2}=0.58$. The kriging method with logarithmic transformation, a spherical function, five neighbors and two as a minimum was used to generate the temperature layer with the coefficient of determination $\mathrm{R}^{2}=0.54$. The IDW method with five neighbors and three as a minimum was used to produce the $\mathrm{H}^{+}$layer with $\mathrm{R}^{2}=0.08$. This value was generated based on concentration data for hydronium 
ions and precipitation reported by the REDDA for 2007 (SMN, 2011). The graph used best represents the data reported by the REDDA for this year (SMA, 2008). The vector kriging layers for the parameters were transformed into raster layers, which generated the following coefficients of determination: $\left[\mathrm{SO}_{2}\right]$, $\mathrm{R}^{2}=0.60$; temperature, $\mathrm{R}^{2}=0.56 ;\left[\mathrm{H}^{+}\right], \mathrm{R}^{2}=0.08$; and $\mathrm{PP}, \mathrm{R}^{2}=0.83$. The $\mathrm{HNO}_{3}$ layer was obtained using the spatial analysis tool ArcToolbox geoprocessor. A kriging interpolation with the spherical variogram model was applied, producing a coefficient of determination $\mathrm{R}^{2}=0.99$.

\section{Results and discussion}

Table II shows the names and classification of artistic and historic monuments. It also shows the physical properties and estimated recession values for the selected sample of monuments made of marble and limestone, and the quarter of the MCMA where they are located as named by the local environmental authority.

The recession of the two kinds of carbonate stones considered herein was constructed using the "raster calculator" tool included in the spatial analysis extension for ArcGIS 9. This tool performs analytical operations using mathematical functions. The process includes applying the damage function, which inserts the raster layer values for the corresponding parameters. These layers represent a terrestrial space property through a series of square cells of equal size (pixels). The raster model is appropriate for representing continuous variables in space, such as meteorological and air pollution variables (Moreno, 2006). The terrestrial space properties were the independent variables in the Lipfert function (Lipfert, 1989). Although somewhat arbitrary for comparison within the area of study, the value levels of the four variables in the Lipfert function were divided into five color ranks.

First, the $\left[\mathrm{SO}_{2}\right]$ layer is shown in Figure 1, which includes the monument locations (Tables II and III). Eighteen sites are in the two higher color ranks, eight in the intermediate, and five in the two lower color ranks. The spatial distribution of $\left[\mathrm{HNO}_{3}\right]$ is shown in Figure 2, with 23 sites in the two higher color ranks, five in the intermediate color ranks, and four in the lower color ranks.

Table II. Physical properties and estimated recession values (microns) in 2007, with Lipfert function for carbonate stones.

\begin{tabular}{|c|c|c|c|c|}
\hline $\begin{array}{l}\text { No. } \\
\text { in } \\
\text { map }\end{array}$ & Name & $\begin{array}{l}\text { Density } \\
\left(\mathrm{g} \mathrm{cm}^{-3}\right)\end{array}$ & $\begin{array}{l}\text { Porosity } \\
\quad(\%)\end{array}$ & $\begin{array}{l}\text { Surface } \\
\text { recession } \\
\quad(\mu \mathrm{m})\end{array}$ \\
\hline 1 & $\begin{array}{l}\text { Palacio de Bellas Artes (Palace of Fine Arts) } \\
\text { (Carrara white marble) }\end{array}$ & 2.69 & 0.37 & 13.09 \\
\hline 2 & $\begin{array}{l}\text { Hemiciclo a Juárez (Hemicycle to Benito Juárez) } \\
\text { (Carrara white marble) }\end{array}$ & 2.69 & 0.37 & 13.88 \\
\hline 3 & $\begin{array}{l}\text { Base de la Columna de la Independencia (statues in } \\
\text { the base of the Independence Column })^{c} \\
\text { (Carrara white marble) }^{c}\end{array}$ & 2.69 & 0.37 & 14.73 \\
\hline 4 & $\begin{array}{l}\text { Gargoyle on the façade of the Museo Nacional del } \\
\text { Virreinato (National Museum of the Viceroyship) } \\
\text { (limestone) }\end{array}$ & $1.3-1.6$ & $34-40$ & 14.88 \\
\hline 5 & $\begin{array}{l}\text { Monumento a los Niños Héroes (Monument to the } \\
\text { Heroic Cadets) }^{\mathrm{c}} \text { (Carrara white marble) }\end{array}$ & 2.69 & 0.37 & 14.98 \\
\hline 6 & $\begin{array}{l}\text { Monument to Christopher Columbus (Pedestal) } \\
\text { (red limestone) }\end{array}$ & $2.2-2.6$ & $5-20$ & 15.60 \\
\hline
\end{tabular}

\footnotetext{
${ }^{\mathrm{b}}$ Artistic monuments; ${ }^{\mathrm{c}}$ historical monuments.
} 

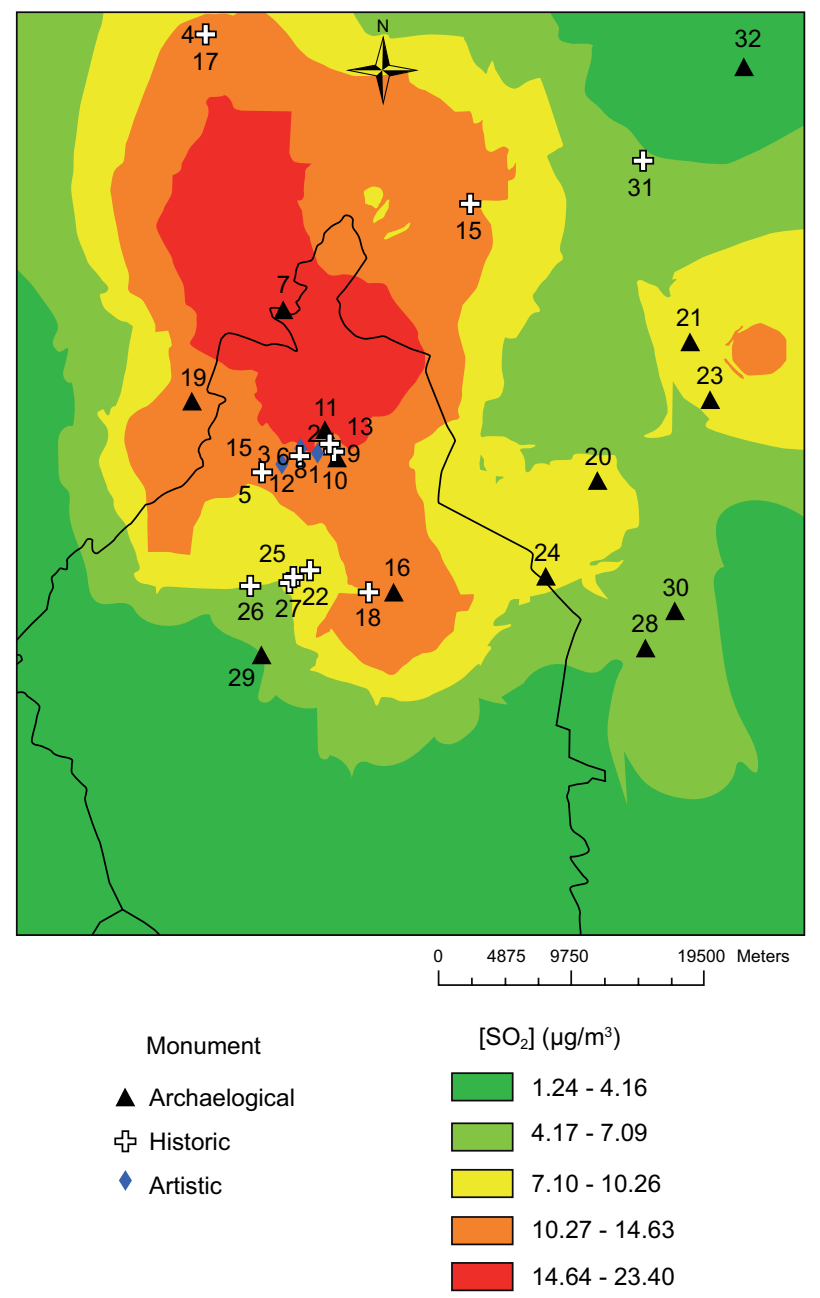

Fig. 1. Map of annual average sulfur dioxide concentrations $\left[\mathrm{SO}_{2}\right]\left(\mu \mathrm{g} \mathrm{m}^{-3}\right)$ for 2007 .

By contrast, the $[\mathrm{H}+]$ (Fig. 3), shows no site in the two higher color ranks, 19 in the intermediate level, and 12 in the two lower ranks. Following the same trend, with regard to precipitation (Fig. 4), only three sites are located in the two higher color ranks, 13 in the intermediate level, and 16 sites in the two lower levels.

Figure 5 overlays the distribution of marble and limestone sites with the 2007 spatial distribution of their respective recession rates. They were calculated with the "raster calculator", applying the Lipfert function using the layers shown in Figures 1-4. For 2007, two of the four marble sites in Table II, are in the intermediate range of recession and the other two are in the lower levels (Fig. 5). Also, the two limestone monuments included in Table II (Fig. 5) are in the intermediate range.
Table II shows recession values for the Palacio de Bellas Artes (13.09 $\mu \mathrm{m})$, the base of the Columna de la Independencia $(14.73 \mu \mathrm{m})$, and the Monumento a los Niños Héroes $(14.88 \mu \mathrm{m})$, all made of marble. They are on a straight line $4.4 \mathrm{~km}$ in length. Of the Lipfert variables, precipitation seems to be the variable with the largest difference. The base of the monument to Christopher Columbus, made of limestone and located only $1.4 \mathrm{~km}$ from the Palacio de Bellas Artes, shows the highest recession value $(15.60 \mu \mathrm{m})$. The higher $\mathrm{SO}_{2}$ and $\mathrm{HNO}_{3}$ deposition rates on limestone explain the higher recession value.

The sparsity of sites in Figure 5 compared with the previous figures points out that for most of the sites in the sample, recession rates can not be estimated due to the lack of damage function for the kinds of volcanic rocks used as building materials. Let us assume that this kind of materials are also sensitive to $\mathrm{SO}_{2}, \mathrm{HNO}_{3}$ and acid deposition. Table III shows the estimated values of these three pollutants to which those 26 buildings made of volcanic materials were exposed in 2007. Table III could be appended with other 135 buildings made of similar materials extracted from the INAH catalog (INAH, 2015) and located within the modeling domain.

Deterioration maps for materials of the unique cultural heritage in the MCMA are unquestionably needed. This area has many archaeological, historic and artistic monuments that have been designated World Heritage Sites by UNESCO. Some noteworthy monuments include the pre-Hispanic city of Teotihuacan and the Historic Center of Mexico City (CONACULTA, 2003). The Spaniards used the stones taken from pre-Hispanic monuments to build churches, palaces, and government buildings. Some, but much less, historic and artistic monuments were also made of limestone and marble.

The primary material used for the construction of this historic and archaeological heritage was andesite originated from the Chiluca quarries. The Chiluca stone is a virgin rock, a porphyritic andesite augite, consisting mainly of $85 \%$ andesite and $6 \%$ augite. It has a porosity between 15 and $17 \%$ and a density of about $2.23 \mathrm{~g} \mathrm{~cm}^{-3}$. The stone of the Metropolitan Cathedral was found to be a consolidated volcanic rock, friable by weathering. This rock generally comprises $85 \%$ andesite and $15 \%$ hornblende crystals. It has a medium porosity, from 14 to $17 \%$, and its density 
Table III. Estimated concentration values of $\mathrm{H}^{+}, \mathrm{SO}_{2}$ and $\mathrm{HNO}_{3}$ for volcanic stone.

\begin{tabular}{|c|c|c|c|c|}
\hline $\begin{array}{l}\text { No. } \\
\text { in map }\end{array}$ & Name & $\begin{array}{c}\left(\mathrm{H}^{+}\right) \\
\left(\mu \mathrm{mol} \mathrm{L} \mathrm{L}^{-1}\right)\end{array}$ & $\begin{array}{c}\mathrm{SO}_{2} \\
\left(\mu \mathrm{g} \mathrm{m}^{-3}\right)\end{array}$ & $\begin{array}{l}\mathrm{HNO}_{3} \\
\left(\mu \mathrm{g} \mathrm{m}^{-3}\right)\end{array}$ \\
\hline 7 & Archaeological Area of Tenayuca (volcanic stone)* & 7.34 & 25.42 & 1.66 \\
\hline 8 & Monumento a la Revolución (Monument to the Revolution) ${ }^{\mathrm{c}}$ (andesite) & 7.50 & 20.80 & 1.88 \\
\hline 9 & Catedral Metropolitana (Metropolitan Cathedral) ${ }^{\mathrm{b}}$ (andesite) & 7.16 & 19.82 & 1.89 \\
\hline 10 & $\begin{array}{l}\text { Archaeological Area of the Templo Mayor }{ }^{\mathrm{a}} \text { (tezontle, basaltic, andesite } \\
\text { and limestone) }\end{array}$ & 7.16 & 19.58 & 1.91 \\
\hline 11 & Archaeological Area of Tlatelolco ${ }^{\mathrm{a}}$ (volcanic stone) & 7.51 & 19.26 & 1.88 \\
\hline 12 & Columna de la Independencia (Independence Column) ${ }^{\mathrm{c}}$ (andesite) & 7.51 & 19.15 & 1.86 \\
\hline 13 & Iglesia de Santo Domingo (Santo Domingo Church) (pink cantera) & 7.22 & 19.10 & 1.89 \\
\hline 14 & Casa de Morelos ${ }^{\mathrm{b}}$ (basaltic) & 5.61 & 17.50 & 1.36 \\
\hline 15 & National Museum of History ${ }^{\mathrm{b}}$ (volcanic stone) & 7.48 & 16.73 & 1.84 \\
\hline 16 & Archaeological Area of Cerro de la Estrella ${ }^{\mathrm{a}}$ (volcanic stone) & 6.84 & 15.98 & 1.63 \\
\hline 17 & $\begin{array}{l}\text { Museo Nacional del Virreinato (National Museum of the Viceroyship) } \\
\text { (pink stone) }\end{array}$ & 6.70 & 15.68 & 1.22 \\
\hline 18 & Exconvento de Culhuacán (Former Monastery of Culhuacán) ${ }^{b}$ (basaltic) & 7.11 & 15.65 & 1.62 \\
\hline 19 & Area of Archaeological Monuments El Conde ${ }^{\mathrm{a}}$ (basaltic) & 7.34 & 15.22 & 1.70 \\
\hline 20 & Archaeological Area of San Vicente Chimalhuacán ${ }^{a}$ (basaltic) & 3.91 & 11.82 & 1.55 \\
\hline 21 & Archaeological Area of Los Melones ${ }^{\mathrm{a}}$ (volcanic stone) & 3.36 & 10.93 & 1.53 \\
\hline \multirow[t]{2}{*}{22} & Museo Nacional de las Intervenciones (National Museum of the & & & \\
\hline & Interventions $)^{\mathrm{b}}$ (volcanic stone) & 7.65 & 10.91 & 1.65 \\
\hline 23 & Archaeological Area of Huexotla ${ }^{a}$ (basaltic) & 3.27 & 9.97 & 1.55 \\
\hline 24 & Archaeological Area of Los Reyes la Paz (basaltic) & 5.34 & 9.92 & 1.70 \\
\hline 25 & Church of Plaza la Conchita ${ }^{\mathrm{b}}$ (volcanic stone) & 7.65 & 9.46 & 1.69 \\
\hline 26 & El Carmen Museum ${ }^{\mathrm{b}}$ (volcanic stone) & 7.71 & 9.17 & 1.71 \\
\hline 27 & Church of San Juan Bautista ${ }^{\mathrm{b}}$ (volcanic stone) & 7.65 & 9.17 & 1.69 \\
\hline 28 & Archaeological Area of Tlapacoya I ${ }^{\mathrm{a}}$ (basaltic) & 6.69 & 6.63 & 1.59 \\
\hline 29 & Archaeological Area of Cuicuilco ${ }^{\text {a }}$ (volcanic stone) & 6.38 & 6.32 & 1.76 \\
\hline 30 & Area of Archaeological Monuments of Acozac ${ }^{\mathrm{a}}$ (basaltic) & 5.02 & 6.07 & 1.58 \\
\hline 31 & Acolman Colonial Museum ${ }^{\mathrm{b}}$ (volcanic stone) & 4.41 & 5.52 & 1.37 \\
\hline 32 & Area of Archaeological Monuments of Teotihuacan ${ }^{\mathrm{a}}$ (volcanic stone) & 4.46 & 4.37 & 1.36 \\
\hline
\end{tabular}

${ }^{\mathrm{a}}$ Archeological monument; ${ }^{b}$ historical monument; ${ }^{c}$ artistic monument.

* Sources for types of building materials: INAH catalogues.

ranges from 2.32 to $2.27 \mathrm{~g} \mathrm{~cm}^{-3}$, depending on the porosity (Martínez-González, 1992; INAH, 2007; Reyes-García, 2011). In addition, stucco, a plaster and limestone-based composite, was also used, due to the ease of painting walls or decorating interior walls with it (Martínez-González, 1992).

The pink stone of Tepotzotlán found in the Museo Nacional del Virreinato is a devitrified tuff (low density and very porous), consisting of a siliceous paste made almost entirely of tridymite, which is included in the tectosilicate group. It has an unhealthy layer of weathered clay, organic in appearance. It contains a fraction of sodium plagioclase. This stone has a very high porosity, from 40 to $55 \%$, and its density is low, ranging from 1.52 to $1.66 \mathrm{~g} \mathrm{~cm}^{-3}$
(Martínez-González, 1992). Similar petrophysical properties were also found in the stones from the Valley of Mexico used by the Aztecs to make buildings such as the Templo Mayor, in which the main building stone is called tezontle. In Náhuatl, the Aztec language, tezontle is the name for extrusive volcanic basaltic andesite scoria. These buildings were demolished by the Spaniards in order to use the materials for the construction of the Metropolitan Cathedral and other colonial constructions such as the Palace of the Dukes of Heras Soto (Wedekind et al., 2011).

Due to the abundance of andesite, tezontle and tuff stone (Pirella and Ramírez, 2001) in the cultural heritage of the MCMA, the need for specific damage 


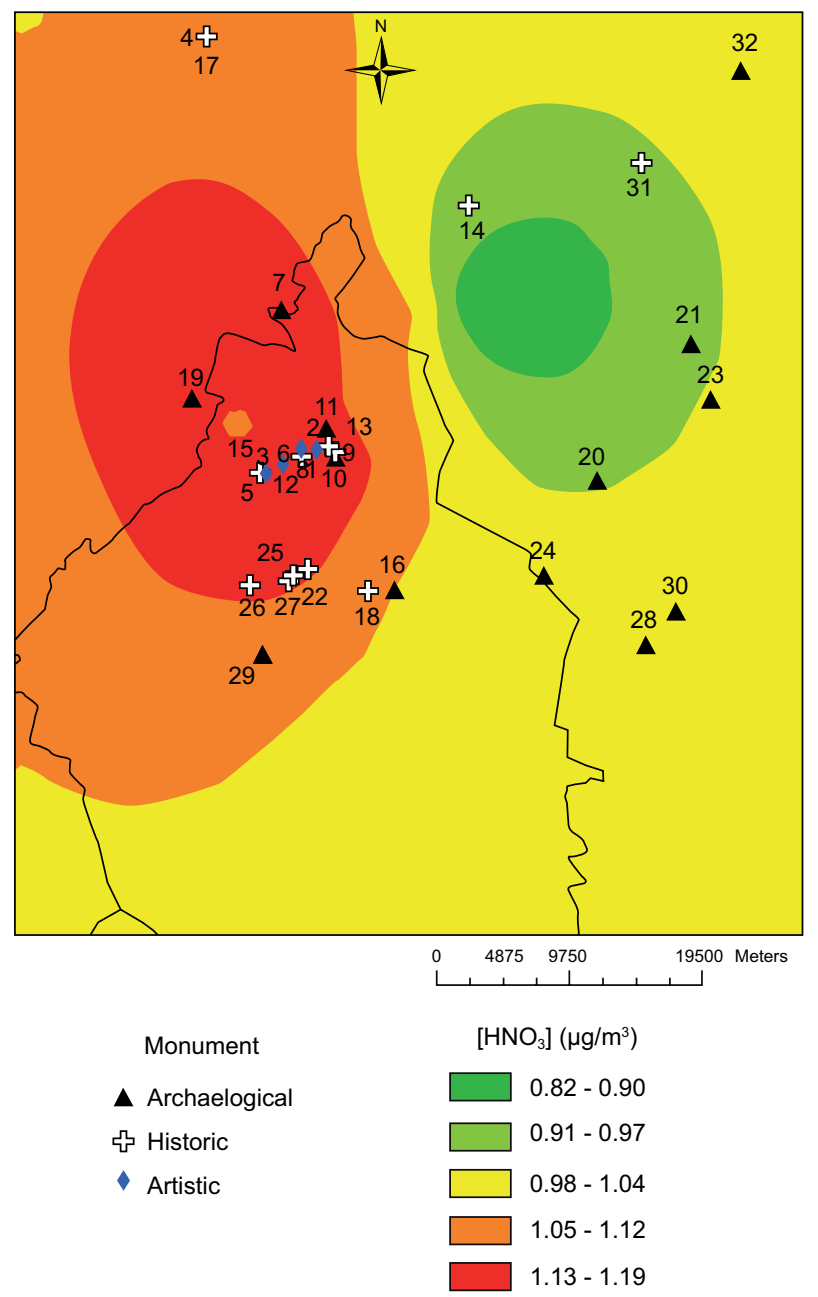

Fig. 2. Map of annual average sulfur nitric acid concentrations $\left[\mathrm{HNO}_{3}\right]\left(\mu \mathrm{g} \mathrm{m}^{-3}\right)$ for 2007.

functions is evident. Additionally, these materials may also be sensitive to other pollutants not discussed here.

Finally, Table IV shows the estimated recession values for limestone, using the Lipfert function with air pollution and meteorological long-term annual period mean values for 1981-2000 in some European cities (Grossi et al., 2008). This table also contains limestone recession values estimated for 1990 in the five geographical areas used by the Metropolitan Environmental Commission to divide the MCMA. The historical data of pollutants and meteorological parameters used for (3) and the Lipfert function were obtained from local monitoring and meteorological networks (SMA, 2011). In 1990, in the MCMA, recession in the downtown area (CE) was close to the

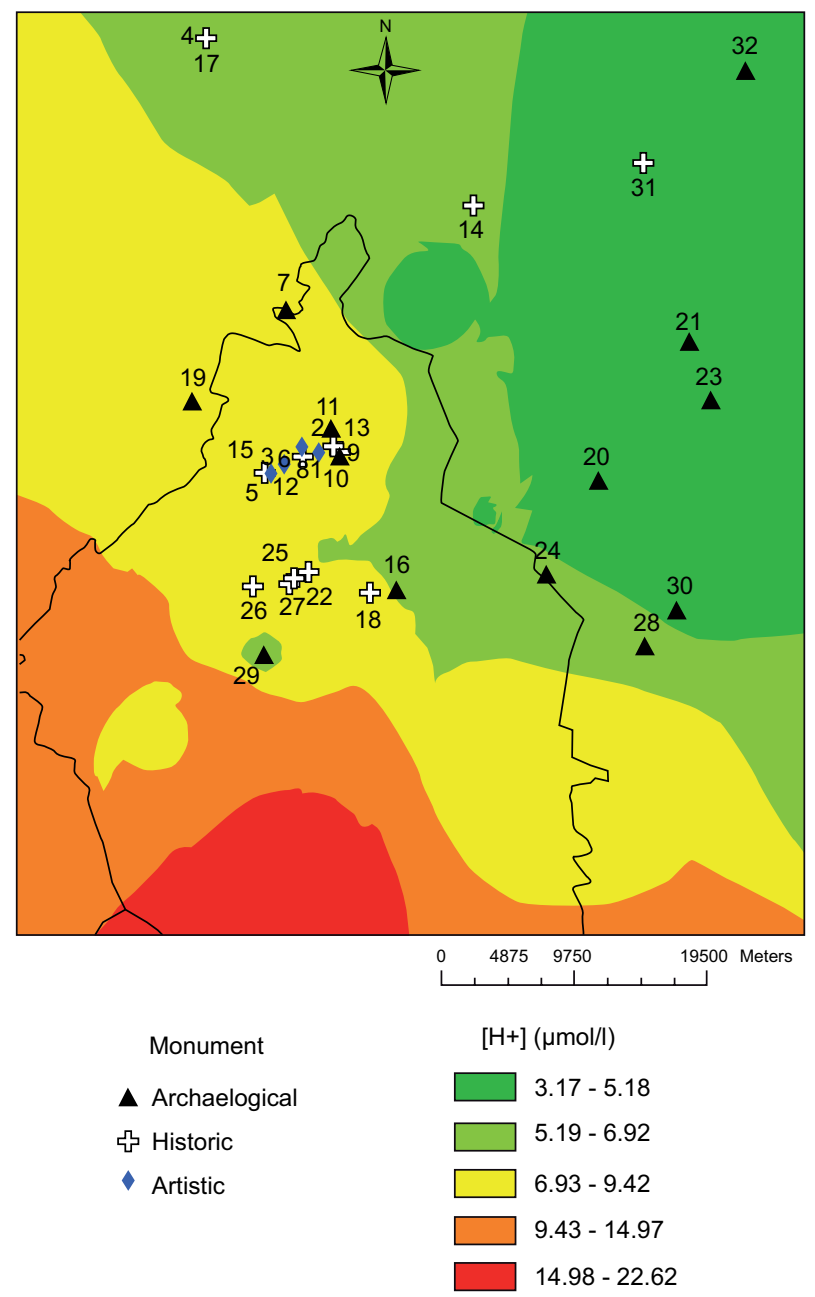

Fig. 3. Map of annual average hydronium ion concentrations $\left[\mathrm{H}^{+}\right]\left(\mu \mathrm{mol} \mathrm{L}{ }^{-1}\right)$ for 2007.

Table IV. Estimated recession values for limestone (19812000) in European cities and MCMA areas (1990).

\begin{tabular}{llc}
\hline Country/area & Site/area & Limestone $(\mu \mathrm{m})$ \\
\hline Spain & Oviedo $^{\mathbf{a}}$ & 24 \\
France & Paris $^{\mathbf{a}}$ & 16 \\
Czech Republic & Prague $^{\mathbf{a}}$ & 13 \\
MCMA & Northwest $_{\text {NOMA }}$ & 19 \\
Northeast & 17 \\
MCMA & Downtown & 23 \\
MCMA & Southwest & 17 \\
MCMA & Southeast & 13 \\
\hline
\end{tabular}

${ }^{\mathrm{a}}$ Grossi, 2008. 


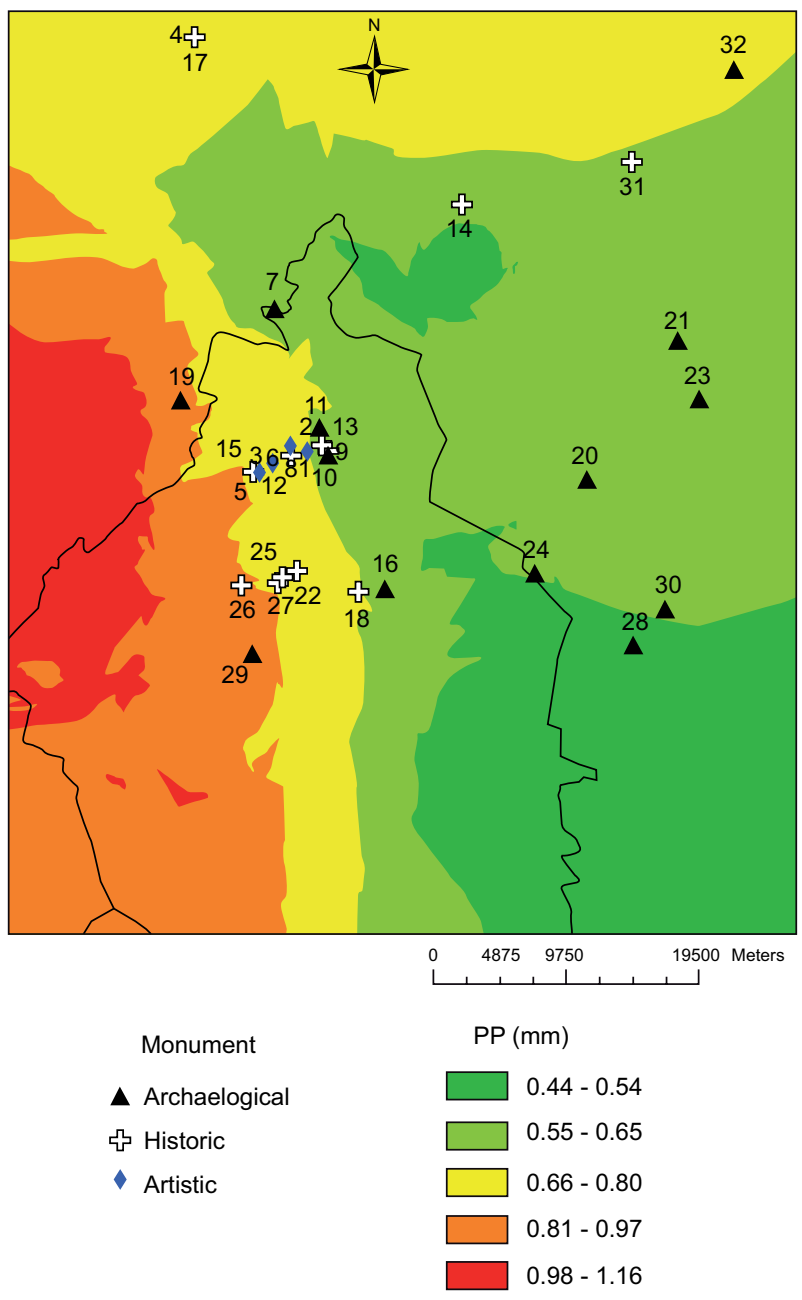

Fig. 4. Map of accumulated annual precipitation PP (m) for 2007.

value reported for Oviedo. The northeast (NE) and southwest (SW) areas had recession values similar to those reported for Paris. Values for the southeast (SE) area were similar to those for Prague. From 1990 to 2007 , the recession rates decreased by a factor of 1.3-1.5 in the MCMA, basically due to reductions in $\mathrm{SO}_{2}$ emissions.

\section{Conclusions}

Most studies on cultural heritage deterioration in the MCMA have focused on characterizing the damage to the materials of specific monuments for restoration purposes. The deterioration of cultural heritage in Mexico has also been attributed principally to acid rain, as the primary cause of damage to materials,

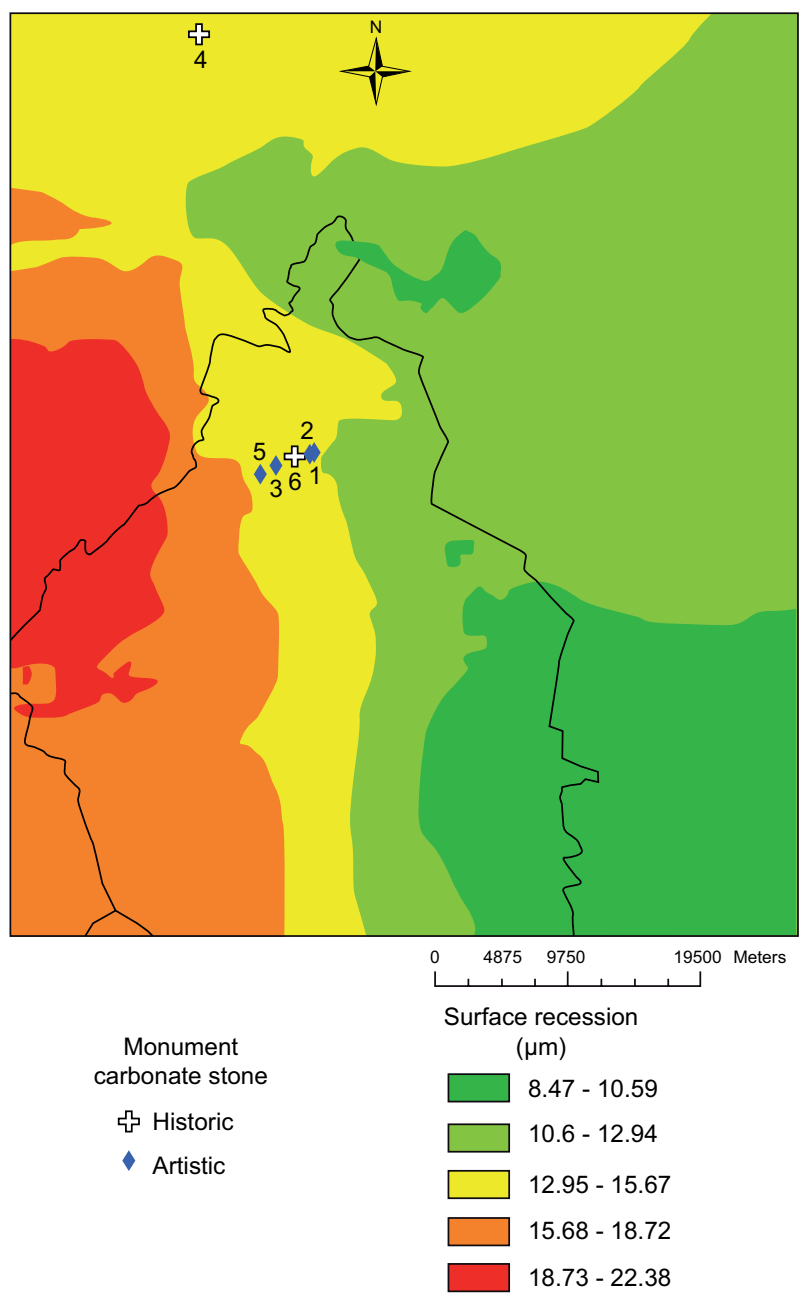

Fig. 5. Map of recession in marble and limestone for the year 2007.

but dry deposition of $\mathrm{SO}_{2}, \mathrm{NO}_{2}$ and $\mathrm{HNO}_{3}$ may also contribute.

To date, the only existing maps in Mexico for damage to building materials are for corrosion of metals.

To the best of our knowledge, this is the first work in Mexico that provides a spatial distribution of existing historical and cultural heritage carbonate stone at risk of deterioration. This was done by mapping areas of corrosion or deterioration rates. Historic and artistic monuments in these areas are susceptible to damage due to pollution and weather conditions.

In this work, maps of atmospheric concentrations of $\mathrm{SO}_{2}$ and $\mathrm{HNO}_{3}$, precipitation, $\mathrm{pH}$ of rain, 
and other weather parameters in the MCMA were obtained by interpolating data from monitoring stations and air quality models in a GIS. The maps were then overlaid in the GIS, and the Lipfert function was applied at the specific coordinates of a small sample of cultural heritage sites.

In contrast to the building materials used in Europe and the USA, in Central Mexico, andesite tezontle and tuff stone are very abundant building materials at historic and archaeological sites. Paramount to a proper assessment of the deterioration risk of that unique heritage is the creation of damage functions such as Lipfert's function for the specific materials used by the ancient Mexicans and the conquering Spaniards.

Based on the lower density and higher porosity reported for the limestone called Tepotzotlán gargoyle, the use of Lipfert's damage function may have led to an under-estimation of recession values for this kind of carbonate stone found in Mexico's historic monuments. Specific Lipfert's coefficients may also be needed.

In addition to these ad hoc damage functions, recession maps for the cultural heritage in Central Mexico can be improved by: i) including cultural heritage as a criteria for the design of air pollution and deposition monitoring networks, ii) improving emission inventories, and iii) using air quality models that are able to properly represent urban and complex terrain meteorology.

\section{Acknowledgments}

We wish to acknowledge the valuable comments and questions provided by the referees of this and a previous submission, who enabled us to refocus this work. We also wish to thank the following institutions:

Consejo Nacional de Ciencia y Tecnología (CONACYT) for the doctoral scholarship that facilitated this study and the 2006 SEMARNAT/ CONACYT projects 23801 and 23496.

Laboratorio de Química Arqueológica y Conservación of the Instituto de Investigaciones Antropológicas, UNAM, and Sistema de Monitoreo Atmosférico, of Mexico City, for their support in locating information.

Dirección de Registro Público de Monumentos y Zonas Arqueológicas, Coordinación Nacional de
Monumentos Históricos, INAH, and Coordinación Nacional del Servicio Meteorológico Nacional, CONAGUA, for access to unpublished databases.

Escuela Nacional de Conservación, Restauración y Museografía Manuel del Castillo Negrete, CONACULTA/INAH, for the information provided.

\section{References}

Alonso E. and L. Martínez, 2003. The role of environmental sulfur on degradation of ignimbrites of the Cathedral in Morelia, Mexico. Build. Environ. 38, 861-867.

DOI: 10.1016/S0360-1323(03)00023-4

Allen G.C., A. El-Turki, K.R. Hallam, D. McLaughlin and M. Stacey, 2000. Role of $\mathrm{NO}_{2}$ and $\mathrm{SO}_{2}$ on the degradation of limestone. Brit. Corros. J. 35, 35-38. DOI: $10.1179 / 000705900101501047$

ArcGIS 9, 2008. Software ArcGIS 9 ArcMap Version 9.3. Environmental Systems Research Institute (ESRI), New York, USA.

ASTM, 1979. ASTM C503-89. Standard specification for marble dimension stone. American Society for Testing and Materials, Philadelphia.

ASTM, 1996. ASTM C568-89 (reapproved 1996). Standard specification for limestone dimension stone. American Society for Testing and Materials, Philadelphia.

Baedecker P.A., M.M. Reddy, K.J. Reimann and C.A. Sciammarella, 1992. Effects of acidic deposition on the erosion of carbonate stone - experimental results from the U.S. National Acid Precipitation Assessment Program (NAPAP). Atmos. Environ. B 26, 147-158. DOI: 10.1016/0957-1272(92)90018-N

Baedecker P.A. and M.M. Reddy, 1993. The erosion of carbonate stone by acid rain. J. Chem. Edu. 70, 104-108. DOI: 10.1021/ed070p104

Bonazza A., P. Messina, C. Sabbioni, C.M. Grossi and P. Brimblecombe. 2009. Mapping the impact of climate change on surface recession of carbonate buildings in Europe. Sci. Total Environ. 407, 2039-2050.

DOI: $10.1016 /$ j.scitotenv.2008.10.067

Bravo H.A., 1960. Variation of different pollutants in the atmosphere of Mexico City. JAPCA J. Air. Waste Ma. 10, 447-449.

DOI: $10.1080 / 00022470.1960 .10467956$

Bravo H.A., M.G. Reyes, R.J. Torres and J.L. Torres, 1994. Soiling on Mexican monuments, the experience of cleaning and its costs. 87th Annual Meeting of the Air \& Waste Management Association, paper 94 MP1.03. 
Bravo H.A., M.G. Reyes and R.J. Torres, 1995. Preliminary studies on the restoration of sculptures of the Metropolitan Cathedral of Mexico City. 88th Annual Meeting of the Air \& Waste Management Association, Paper 94-RA117B.02. San Antonio, Texas, June, 18-23.

Bravo H.A., M.I.R Saavedra., P.A. Sánchez, R.J. Torres and L.M.M. Granada, 2000. Chemical composition of precipitation in a Mexican Maya region. Atmos. Environ. 34, 1197-1204.

DOI: $10.1016 / \mathrm{S} 1352-2310(99) 00305-2$

Bravo H.A., R. Soto, R. Sosa, P. Sánchez, A.L. Alarcán, J. Kahl and J. Ruiz, 2006. Effect of acid rain on building material of the El Tajín archeological zone in Veracruz, Mexico. Environ. Pollut. 144, 655-660.

DOI: 10.1016/j.envpol.2005.12.052

Brimblecombe P. and C.M. Grossi, 2008. Millennium-long recession of limestone façades in London. Environ. Geol. 56, 463-471.

DOI: $10.1007 / \mathrm{s} 00254-008-1465-\mathrm{z}$

Canada R., 2006. Análisis exploratorio de datos espaciales: gráficos de distribución. In: Sistemas y análisis de la información geográfica (A. Moreno, Coord.). Editorial Rama, 745-764.

Canada R., M. Vidal and A. Moreno, 2010. Interpolación espacial y visualización cartográfica para el análisis de la justicia ambiental: Ensayo metodológico sobre la contaminación por partículas atmosféricas en Madrid. Secretaría de Publicaciones de la Universidad de Sevilla, 691-715.

Cobourn W.G., 1993. Laboratory measurements of sulfur dioxide deposition velocity on marble and dolomite stone surfaces. Atmos. Environ. 27B, 193-201.

DOI: 10.1016/0957-1272(93)90005-Q

CONACULTA, 2003. Atlas de infraestructura cultural de México. Cap. III. Patrimonio. Consejo Nacional para la Cultura y las Artes, México, 33-94.

Cuevas J.A., 2014. Correlación entre ácido nítrico gaseoso y ozono en un sitio receptor de smog fotoquímico de la Ciudad de México. Ms.C. thesis. Posgrado en Ciencias de la Tierra, UNAM, Mexico.

Cultrone G., O. Rodríguez-Navarro and E. Sebastian, 2004. Limestone and brick decay in simulated polluted atmosphere the role of particulate matter. In: Air pollution and cultural heritage (C. Saiz-Jiménez, Ed.). Taylor \& Francis, London, 141-146.

DOI: $10.1201 / \mathrm{b} 17004-20$

De Foy B., M. Zavala, N. Bei and L.T. Molina, 2009a. Evaluation of WRF mesoscale simulations and particle trajectory analysis for the MILAGRO field campaign. Atmos. Chem. Phys. 9, 4419-4438.

DOI: 10.5194/acp-9-4419-2009

De Foy B., N.A. Krotkov, N. Bei, S.C. Herndon, L.G. Huey, A.-P. Martínez, L.G. Ruiz- Suárez, E. C. Wood, M. Zavala and L.T. Molina, 2009b. Hit from both sides: Tracking industrial and volcanic plumes in Mexico City with surface measurements and OMI $\mathrm{SO}_{2}$ retrievals during the MILAGRO field campaign. Atmos. Chem. Phys. 9, 9599-9617.

DOI: 10.5194/acp-9-9599-2009

Delopoulou P. and D. Sikiotis, 1992. A comparison of the corrosive action on Pentelic marble of nitrates and sulphates with the action of nitrogen oxides and sulphur dioxide. Atmos. Environ. 26B, 183-188.

Denby B., J. Horalek, S. Walker, K. Eben and J. Fiala, 2005. Interpolation and assimilation methods for European scale air quality assessment and mapping. Part 1: Review and recommendations. European Topic Centre on Air and Climate Change, 14-18.

Denby B., I. Sundvor, M. Cassiani, P. de Smet, F. de Leeuw and J. Horálek, 2010. Spatial mapping of ozone and $\mathrm{SO}_{2}$ trends in Europe. Sci. Total Environ. 408, 4795 4806. DOI: 10.1016/j.scitotenv.2010.06.021.

Fassina V., 1978. A survey on air pollution and deterioration of stonework in Venice. Atmos. Environ. 32, 2205-2211. DOI: 10.1016/0004-6981(78)90176-2

Fenn M.E, L.I. de Bauer, K. Zeller, A. Quevedo, C. Rodríguez and T. Hernández-Tejada, 2002. Nitrogen and sulfur deposition in the Mexico City air basin: Impacts on forest nutrient status and nitrate levels in drainage waters. In: Urban air pollution and forest: Resources at risk in the Mexico City air basin. In: Ecological Studies 156 (M.E. Fenn, L.I. de Bauer and T. Hernández-Tejeda, Eds.). Springer, New York, 298-319.

Fenter F., F. Caloz and M. Rossi, 1995. Experimental evidence for the efficient 'dry deposition' of nitric acid on calcite. Atmos. Environ. 29, 3365-3372.

DOI: 10.1016/1352-2310(95)00183-Y

Franzoni E. and E. Sassoni, 2011. Correlation between microstructural characteristics and weight loss of natural stones exposed to simulated acid rain. Sci. Total Environ. 412-413, 278-285.

DOI: $10.1016 /$ j.scitotenv.2011.09.080

García-Escalante J., 2008. Impacto del sector energético de Tula Hidalgo en la calidad del aire de la ZMVM. B.Sc. thesis. Facultad de Química, UNAM, México. García-Reynoso J.A., 2010. Unpublished manuscript. 
Grell G.A., S. Emei, W.R. Stockwell, T. Schoenemeyer, R. Forkel, J. Michalakes, R. Knoche and W. Seild, 2000. Application of a multiscale, coupled MM5/chemistry model to the complex terrain of the VOLTAP valley campaign. Atmos. Environ. 34, 1435-1453.

Grossi C.M., M. Murray and R.N. Butlin, 1995. Response of porous building stones to acid deposition. Water Air Soil Pollut. 85, 2707-2712.

DOI: $10.1007 / \mathrm{BF} 01186244$

Grossi C.M. and M. Murray, 1999. Characteristics of carbonate building stones that influence the dry deposition of acid gases. Constr. Build. Mater. 13, 101-108.

DOI: 10.1016/S0950-0618(99)00019-7

Grossi C.M. and P. Brimblecombe, 2002. The effect of atmospheric pollution on building materials. J. Phys. IV 12, Pr. 10-197.

DOI: $10.1051 /$ jp4:20020460

Grossi C.M. and P. Brimblecombe, 2007. Effect of longterm changes in air pollution and climate on decay and blackening of European stone buildings. Geol. Soc. Spec. Publ. 271, 117-130.

DOI: 10.1144/GSL.SP.2007.271.01.13

Grossi C.M., A. Bonazza, P. Brimblecombe, I. Harris and C. Sabbioni, 2008. Predicting twenty- first century recession of architectural limestone in European cities. Environ. Geol. 56, 455-461.

DOI: $10.1007 / \mathrm{s} 00254-008-1442-6$

Haynie F.H., J.W. Spence and J.B. Upham, 1976. Effects of gaseous pollutants on materials. A chamber study. U.S. Enviromental Protection Agency Report EPA 600/3-76-015.

INAH, 2007. Inventario de la Zona Metropolitana del Valle de Mexico (CD-ROM). Dirección de Registro Público de Monumentos y Zonas Arqueológicos. Instituto Nacional de Antropología e Historia.

INAH, 2015. Inventario de monumentos historicos de los estados: Distrito Federal, Estado de México, Hidalgo, Morelos, Puebla y Tlaxcala (CD-ROM). Coordinación Nacional de Monumentos Históricos, Instituto Nacional de Antropología e Historia.

Inkpen R., H. Viles, C. Moses and B. Baily, 2012. Modelling the impact of changing atmospheric pollution levels on limestone erosion rates in central London, 1980-2010. Atmos. Environ. 61, 476-481.

DOI: $10.1016 /$ j.atmosenv.2012.07.042

Jáuregui E., D. Klaus and W. Lauer, 1981. Una primera estimación del transporte de $\mathrm{SO}_{2}$ sobre la Ciudad de México. Geofís. Int. 20, 55-79.
Jaynes S.M. and R.U. Cooke, 1987. Stone weathering in southeast England. Atmos. Environ. 21, 1601-1622. DOI: 10.1016/0004-6981(87)90321-0

Kirkitsos P. and D. Sikiotis, 1995. Deterioration of Pentelic marble, Portland limestone and Baumberger sandstone in laboratory exposures to gaseous nitric acid. Atmos. Environ. 29, 77-86. DOI: $10.1016 / 1352-2310(94) 00230-\mathrm{I}$

Kirkitsos P. and D. Sikiotis, 1996. Deterioration of Pentelic marble, Portland limestone and Baumberger sandstone in laboratory exposures to $\mathrm{NO}_{2}$ : A comparison with exposures to gaseous $\mathrm{HNO}_{3}$. Atmos. Environ. 30, 941950. DOI: 10.1016/1352-2310(95)00297-9

Kucera V., 2005. Model for multi-pollutant impact and assessment of threshold levels for cultural heritage. Final report. EU 5FP RTD Project, 52 pp.

Kucera V., J. Tidblad, K. Kreislova, D. Knotkova, M. Faller, D. Reiss, R. Snethlage, T. Yates, J. Henriksen, M. Schreiner, M. Melcher, M. Ferm, R-A. Lefevre and J. Kobus, 2007. UN/ECEICP materials: Dose-response functions for the multi-pollutant situation. Water Air Soil Poll. 7, 249-258.

DOI: $10.1007 / \mathrm{s} 11267-006-9080-\mathrm{z}$

Kumar J.D., M. Sabesan, A. Das, N.V. Vinithkumar and R. Kirubagarn, 2011. Evaluation of interpolation technique for air quality parameters in Port Blair, India. Univers. J. Environ. Res. Technol. 1, 301-310.

Lipfert F.W., 1989. Atmospheric damage to calcareous stones: Comparison and reconciliation of recent experimental findings. Atmos. Environ. 23, 415-429. DOI: 10.1016/0004-6981(89)90587-8

Livingston R.A., 1992. Graphical methods for examining the effects of acid rain and sulfur dioxide on carbonate stones. In: Proceedings of the 7th International Congress on Deterioration and Conservation of Stone (J. Delgado, F. Henriques and J. Telmo, Eds.), 375-86.

Mariaca L., J. Genesca, J. Uruchurtu and L.S. Hernandez, 1999. Corrosividad atmosferica (MICAT-MÉXICO). Plaza y Valdés, Mexico, 209 pp.

Martínez-González, G.M., 1992. Aspectos fisicoquímicos del deterioro y conservación de monumentos históricos de piedra. Ph.D. thesis. Universidad Autónoma Metropolitana, México, $215 \mathrm{pp}$.

Massey S.W., 1999. The effects of ozone and NOx on the deterioration of calcareous stone. Sci. Total Environ. 227, 109-121.

DOI: 10.1016/S0048-9697(98)00409-4 
Moreno A., 2006. Las capas raster: conceptos básicos, tipos de tratamientos y visualización. In: Sistemas y análisis de la información geográfica (A. Moreno, Coord.). Editorial RA-MA, Spain, 587-598.

Moya M., Grutter M. and Báez A., 2004. Diurnal variability of size differentiated inorganic aerosols and their gas phase precursors during January and February of 2003 near downtown Mexico City. Atmos. Environ. $38,5651-5661$.

DOI: /10.1016/j.atmosenv.2004.05.045

Nord A.G. and K. Tronner, 1995. Effect of acid rain on sandstone: The Royal Palace and the Riddarholm Church, Stockholm. Water Air Soil Poll. 85, 27192724. DOI: $10.1007 / \mathrm{BF} 01186245$

Orrayave C., F. Echeverría, F. Herrera, J. Delgado, D. Aragón and M. Morcillo, 2002. $\mathrm{NO}_{2}$ measurements in atmospheric corrosion studies. In: Outdoor atmospheric corrosion. ASTM

STP 1421 (H.E. Townsend, Ed.). American Society for Testing and Materials International, West Conshohocken, PA.

Ortiz-García C.F., H.D. Laguette-Rey and L.I. de Bauer, 2002. Effects of oxidants in ambient air on annual crops in the basin of Mexico. In: Urban air pollution and forest: Resources at risk in the Mexico City air basin. Ecological Studies 156. (M.E. Fenn, L.I. de Bauer and T. Hernández-Tejeda, Eds.). Springer, New York, 320-334.

PEMBU, 2011. Programa de Estaciones Meteorológicas del Bachillerato Universitario. Available at: http:// www.ruoa.unam.mx/pembu/.

Philips L.D. and G.D. Marks, 1996. Spatial uncertainty analysis: Propagation of interpolation errors in spatially distributed models. Ecol. Model. 91, 213-229.

Meli-Piralla R. and A. Ramírez-Sánchez, 2001. La rehabilitacion de la Catedral Metropolitana de la Ciudad de México. Revista Digital Universitaria 2, June. Available at: http://www.revista.unam.mx/vol.2/num2/proyec1/.

Reddy M.M., S.I. Sherwood and B. Doe, 1985. Modeling limestone dissolution by acid rain. Research and Design 85, 383-388.

Reyes J., F. Corvo, Y. Espinosa-Morales, B. Dzul, T. Pérez, C. Valdés, D. Aguilar and P. Quintana, 2011. Influence of air pollution on degradation of historic buildings at the urban tropical atmosphere of San Francisco de Campeche city, Mexico. In: Monitoring, control and effects of air pollution (A.G. Chmielewski, Ed.), 201226. DOI: $10.5772 / 18739$
Reyes-García M., 2011. Personal communication.

Roekens E. and R. Van Grieken, 1989. Rates of air pollution induced surface recession and material loss for a cathedral in Belgium. Atmos. Environ. 23, 271-277. DOI: 10.1016/0004-6981(89)90119-4

Rojas-Avellaneda D., 2007. Spatial interpolation techniques for estimating levels of pollutant concentrations in the atmosphere. Revista Mexicana de Física 53, 447-454.

Rosas-Pérez I., L.G. Ruiz-Suárez, A. Jazcilevich Diamant, A. García Reynoso, M. Grutter de la Mora, R. Torres Jardón, B.E. Mar Morales, J.M. Hernández Solís, A. Báez Pedrajo, H. Padilla Gordon, M.C. Torres Barrera and R. Steinbrecher, 2006. Relación ciudad-bosque en el centro de Mexico (trazadores e indicadores de reactividad fotoquímica y especiación de emisiones biogénicas). 1er. reporte. Proyecto PAPITT: IN118706. Centro de Ciencias de la Atmósfera, UNAM. Mexico.

Sabbioni C., 2003. Mechanisms of air pollution damage to stone. In: The effects of air pollution on the built environment (P. Brimblecombe, Ed.), 63-106.

DOI: 10.1142/9781848161283_0003

Saiz-Jiménez C. and B. Hermosin, 2004. Black crusts in the European built environment. Corros. Rev. 22, 381-293. DOI: 10.1515/CORRREV.2004.22.5-6.381

Sikiotis D. and P. Kirkitsos, 1995. The adverse effects of nitrates on stone monuments. Sci. Total Environ. 171, 173-182. DOI: 10.1016/0048-9697(95)04718-8

Skoulikidis T. and P. Papakonstantinou-Ziotis, 1981. Mechanism of sulphation by atmospheric sulphur dioxide of the limestones and marbles of the ancient monuments and statues. 1. Observations in situ (Acropolis) and laboratory measurements. Brit. Corros. J. 16, 63-69. DOI: $10.1179 / 000705981798274986$

SMA, 2008. Secretaria del Medio Ambiente del Gobierno del Distrito Federal. Informe de la Calidad del Aire en la Zona metropolitana del valle de Mexico, Estados y tendencias 1990-2007, $50 \mathrm{pp}$.

SMA, 2009. Calidad del aire en la Ciudad de México. Informe 2008. Secretaría del Medio Ambiente, Gobierno del Distrito Federal, 142 pp.

SMA, 2011. Sistema de Monitoreo Atmosférico SIMAT. Secretaría del Medio Ambiente, Gobierno del Distrito Federal. Available at: http://www.aire.cdmx.gob.mx (last accessed on April 28, 2011).

SMN, 2011. Servicio Meteorológico Nacional, México. Available at: http://smn.cna.gob.mx/ (last accesed on January 17, 2010). 
Tarbuck E.J., F.K. Lutgens and D. Tasa, 2005. Ciencias de la tierra. Pearson Educación, Madrid, 736 pp.

Tzanis C., C. Varotsos, M. Ferm, J. Christodoulakis, M.N. Assimakopoulos and C. Efthymiou, 2009. Nitric acid and particulate matter measurements at Athens, Greece, in connection with corrosion studies. Atmos. Chem. Phys. 9, 8309-8316. DOI: 10.5194/acp-9-8309-2009

Tidblad J., V. Kucera and A.A. Mikhailov, 1998. UN ECE ICP on effects on materials, statistical analysis of 8 year materials exposure and acceptable deterioration and pollution levels, Stockholm. Swedish Corrosion Institute, Report no. 30, 49 pp.

Tidblad, J., V. Kucera, A.A. Mikhailov, J. Henriksen, K. Kreislova, T. Yates, B. Stockle and M. Schreiner, 2001. UN ECE ICP materials: Dose-response functions on dry and wet acid deposition effects after 8 years of exposure. Water Air Soil Poll. 130, 1457-1462.

DOI: 10.1023/A:1013965030909

Venkatram A., 1988. On the use of kriging in the spatial analysis of acid precipitation data. Atmos. Environ. 22, 1963-1975. DOI: 10.1016/0004-6981(88)90086-8

Watt J., 2007. Cultural heritage stock at risk from air pollution. In: E. Andrews, R. Machin et al., 2007. In: Highway and urban environment. Proceedings of the 8th Highway and Urban Environment Symposium (G.M. Morrison and S. Rauch, Eds.), 223-232.

Webb A.H., R.J. Bawden, A.K. Busby and J.N. Hopkins, 1992. Studies on the effects of air pollution on limestone degradation in Great Britain. Atmos. Environ. B 26, 165- 81. DOI: /10.1016/0957-1272(92)90020-S
Wedekind W., J. Ruedrich and S. Siegesmund, 2011. Natural building stones of Mexico- Tenochtitlan: their use, weathering and rock properties at the Templo Mayor, Palace Heras Soto and the Metropolitan Cathedral. Environ. Earth Sci. 63, 1787-1798.

DOI: $10.1007 / \mathrm{s} 12665-011-1075-\mathrm{z}$

WHO, 2006. Air quality guidelines global update 2005. World Health Organization Regional Office for Europe. Copehhagen, Denmark.

Winkler E.M., 1997. Stone in architecture: Properties, durability. Springer-Verlag, New York.

Wood E.C., S.C. Herndon, T.B. Onasch, J.H. Kroll, M.R. Canagaratna, C.E. Kolb, D.R. Worsnop, J.A. Neuman, R. Seila, M. Zavala and W.B. Knighton, 2009. A case study of ozone production, nitrogen oxides, and the radical budget in Mexico City. Atmos. Chem. Phys. 9, 2499-2516.

DOI: $10.5194 /$ acp-9-2499-2009

Zheng J., R. Zhang, E.C. Fortner, R.M. Volkamer, L. Molina, A.C. Aiken, J.L. Jimenez, K. Gaeggeler, J. Dommen, S. Dusanter, P.S. Stevens and X. Tie, 2008. Measurements of $\mathrm{HNO}_{3}$ and $\mathrm{N}_{2} \mathrm{O}_{5}$ using ion drift-chemical ionization mass spectrometry during the MILAGRO/MCMA-2006 campaign. Atmos. Chem. Phys. 8, 6823-6838.

DOI: $10.5194 /$ acp-8-6823-2008 